\title{
19. CENOZOIC CALCAREOUS NANNOFOSSILS FROM THE GALICIA MARGIN, OCEAN DRILLING PROGRAM LEG 1031
}

\author{
Wuchang Wei, James A. Bergen, and Joseph Applegate, Department of Geology, Florida State University, \\ Tallahassee, Florida
}

\begin{abstract}
Ocean Drilling Program Leg 103 occupied five sites on the Galicia margin, northwest of the Iberian Peninsula. Two holes (Holes 637A and 638B) yielded significant Cenozoic sedimentary sections ranging from late Miocene to late Pleistocene in age. From the nannofossil stratigraphy, one hiatus is recognized in Hole 637A (2.35-2.4 Ma), whereas two hiatuses (one at 1.9-2.6 Ma and another at 3.5-3.7 Ma) are recognized in Hole 638B. Sediment-accumulation rates for the Cenozoic portions of these two holes have been calculated based on the nannofossil datums. The abundance ratios of Coccolithus pelagicus to Discoaster brouweri for Hole 637A show relatively low values and small fluctuations from 2.5 to $6.5 \mathrm{Ma}$ but sharply increase and then widely fluctuate beginning at about $2.5 \mathrm{Ma}$. This may indicate relatively warmer, more stable surface-water temperatures from 2.5 to $6.5 \mathrm{Ma}$ and cooler, variable surface-water temperatures after $2.5 \mathrm{Ma}$ at Site 637. C. pelagicus/D. brouweri ratios from Hole 638B also show a trend of increasing values with time from late Miocene to late Pliocene, but with more fluctuations and a different pattern from that of Hole 637A.
\end{abstract}

\section{INTRODUCTION}

Ocean Drilling Program (ODP) Leg 103 cored the Galicia margin (April-June 1985), $150 \mathrm{~km}$ west of the northern Iberian Peninsula (Fig. 1), to investigate the deep structure and the history of rifting, subsidence, and sedimentation during the progressive opening of this portion of the North Atlantic. The results from Leg 103 were intended to build on previous drilling results from this margin at nearby Deep Sea Drilling Project (DSDP) Site 398 (Leg 47B; Sibuet, Ryan, et al., 1979), where the deeper portion of the syn-rift sequence was not successfully penetrated.

The Galicia margin is a starved passive ocean margin with a thin sedimentary cover. The continental basement is broken by normal faults into tilted blocks trending north and dipping gently east, forming a series of half-grabens. On the uplifted western sides of some of these blocks, basement and pre-rift sedimentary rocks were believed to crop out, presumably making it possible to drill through the oldest sedimentary strata and into basement on Leg 103.

Five sites were occupied and 14 holes were drilled during Leg 103. The sediments recovered range from Late Jurassic to late Pleistocene in age, and the analysis of the calcareous nannofossil biostratigraphy has been divided into two parts. The Mesozoic section is presented by Applegate and Bergen (this volume), whereas the Cenozoic is discussed in this paper.

Two continuously cored holes (637A and 638B) yielded significant Neogene sedimentary sections. Nannofossils are abundant in these sections, and preservation ranges from poor to good. Range charts and sediment-accumulation rate curves have been prepared for these two holes and the extent of the hiatuses estimated from the curves. In addition, the abundance ratios of Coccolithus pelagicus (cool-water species) to Discoaster brouweri (warm-water species) have been plotted in an attempt to identify possible surface-water temperature changes with time.

Of the twelve other Leg 103 holes: Holes 638A and 641B were operational holes where no cores were taken; Holes $638 \mathrm{C}$, 640A, and $641 \mathrm{C}$ recovered only Cretaceous sediments; two of the six holes at Site 639 (639E and 639F) recovered sediment

\footnotetext{
${ }^{1}$ Boillot, G., Winteręr, E. L., et al., 1988. Proc. ODP, Sci. Results, 103: College Station, TX (Ocean Drilling Program).
}

barren of nannofossils; the other four holes at Site 639 (639A639D) and Hole 641A yielded only minor amounts of Cenozoic sediment and are discussed briefly in this paper.

\section{Methods and Procedures}

The occurrence of abundant nannofossils in the Cenozoic sediments recovered on Leg 103 permitted the preparation of smear slides directly from raw sediment samples. Smear slides were examined using the light microscope, and the distribution of nannofossils was recorded on the range charts. Nannofossil abundances were estimated using the criteria defined by Hay (1970), except that the slides were here examined at $1560 \times$ rather than at $1000 \times$. These criteria are as follows:

$$
\begin{aligned}
& \mathrm{A}=\text { abundant; } 1-10 \text { specimens per field of view at } 1560 \times \\
& \mathrm{C}=\text { common; } 1 \text { specimen per } 2-10 \text { fields of view at } 1560 \times \\
& \mathrm{F}=\text { few; } 1 \text { specimen per } 11-100 \text { fields of view at } 1560 \times \\
& \mathrm{R}=\text { rare; } 1 \text { specimen per } 101-1000 \text { fields of view at } 1560 \times
\end{aligned}
$$

The abundance ratios of Coccolithus pelagicus to Discoaster brouweri from Holes 637A and 638B were determined by counting at least 100 specimens of $C$. pelagicus and $D$. brouweri on random tracks across the slides. If $D$. brouweri was not observed in the first 200 specimens, the $C$. pelagicus $/ D$. brouweri ratio was recorded as 200 .

The state of the preservation in a sample was estimated based on the following criteria:

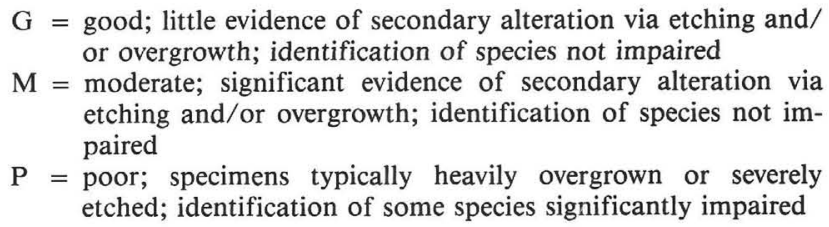

Species considered in this study are listed in the Appendix, arranged alphabetically by generic epithets. Most of the bibliographic references for these taxa are presented by Loeblich and Tappan $(1966,1968,1970 \mathrm{a}$, 1970b, 1971, 1973), van Heck (1979a, 1979b, 1980a, 1980b, 1981a, 1981b, 1982a, 1982b, 1983), and Steinmetz (1984, 1984b, 1985a, 1985b, 1986). Any references not included in the above are listed in the references of this paper.

\section{CALCAREOUS NANNOFOSSIL ZONATION}

The Cenozoic calcareous nannofossil zonation applied in this study (Fig. 2) results from a combination of those proposed by Bukry (1973, 1985), Okada and Bukry (1980), and Gartner 


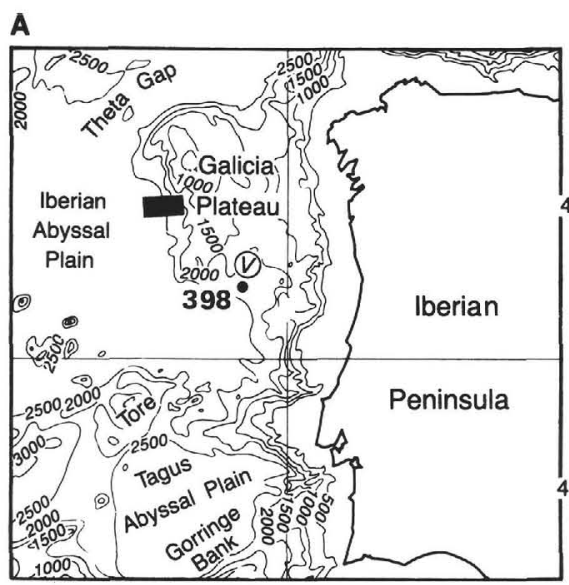

\section{B}

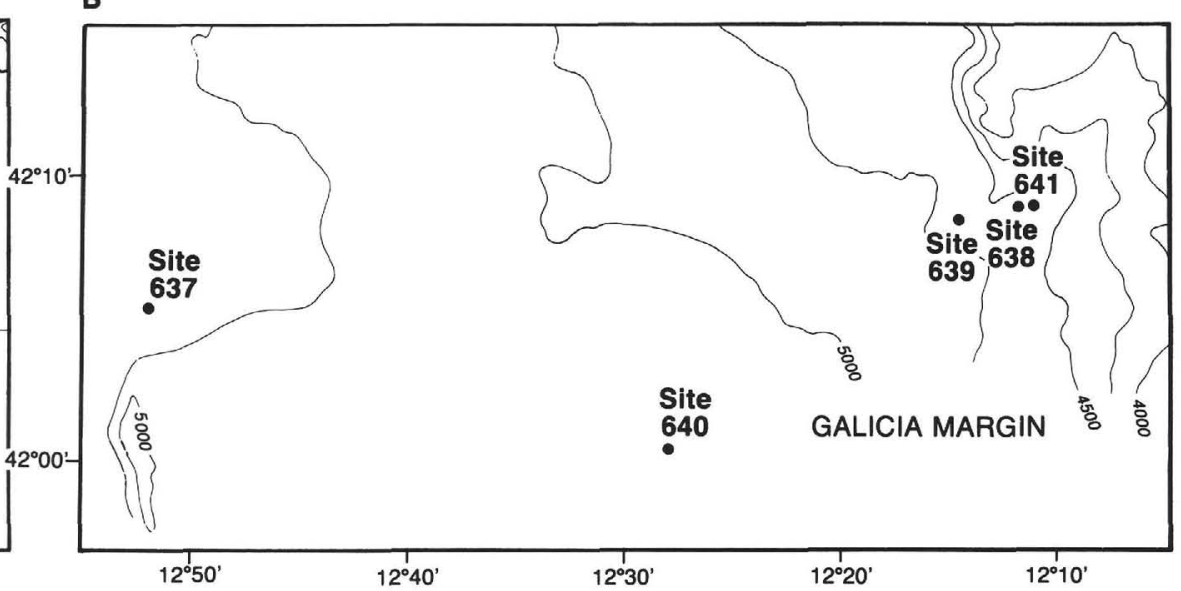

Figure 1. A. General location map of Iberian Peninsula and Galicia margin. Rectangle shows location of Figure 1B. B. Bathymetric map showing location of Leg 103 drill sites.

(1977). The zonation of Bukry $(1973,1985)$ is used only for prePleistocene sections. Gartner's (1977) zonation provides better resolution for the Pleistocene and is used for this part of the column. Because both zonal schemes recognize the Pliocene/ Pleistocene boundary on the basis of the last occurrence (LO) of Discoaster brouweri, there is no discontinuity in the combined zonation adopted in this paper. Calcidiscus macintyrei is used as the earliest Pleistocene zonal name by Gartner (1977), as well as the latest Pliocene subzonal name by Bukry (1973) and Okada and Bukry (1980). This confusion has been subsequently avoided since Bukry renamed the latter as the Discoaster triradiatus Subzone (Bukry, 1985).

Two emendations of the Okada and Bukry (1980) scheme were necessary in studying the Leg 103 samples. One is that the first occurrence datum (FOD) of Pseudoemiliania lacunosa is substituted for the datum level marked elsewhere by the beginning of the acme of Discoaster asymmetricus; a Discoaster asymmetricus acme was not observed in the Leg 103 material. Moreover, environmental control of acmes also greatly hinders their use in biostratigraphic zonations (Bukry, 1981). Pseudoemiliania lacunosa has a distinct FOD near the middle of the Reticulofenestra pseudoumbilica Zone and approximates the Discoaster asymmetricus acme (see Bergen, 1984; Perch-Nielsen, 1985; Lohman, 1986). We also recommend that the FOD of $P$. lacunosa be considered in other areas, especially in mid- to high-latitude areas where $D$. asymmetricus is rare or absent. Pseudoemiliania lacunosa is relatively dissolution resistant and is usually in high abundance where present, thus making its datum level easily recognizable.

The second emendation is that the FOD of Amaurolithus primus be used with that of Amaurolithus delicatus. Many investigators have reported these datums as coincident (Haq and Berggren, 1978; Ellis and Lohman, 1979; Perch-Nielsen, 1985; Lohman, 1986). Amaurolithus primus is scarce in the Leg 103 material and could not be used.

Because the Leg 103 sites are at midlatitudes, some of the marker species of Okada and Bukry's (1980) low-latitude zonation are scarce or absent. The Leg 103 holes were drilled in deep water, especially Site $637(5307 \mathrm{~m})$. According to the calculation proposed by Sclater et al. (1985), the paleodepth of the oldest Cenozoic sediments (upper Miocene) at this site was near 5200 $\mathrm{m}$. Dissolution may have reduced or removed some of the less dissolution-resistant marker species. In addition, trace amounts of reworked material are present in most of the samples examined. All of these factors limit the biostratigraphic resolution, and some zones and/or subzones cannot be reliably discrimi- nated. Dashed lines are used on the range charts to indicate problems in discerning these boundaries. Reasons for the uncertainty about the positions of these boundaries at each site are subsequently discussed. A summary of the calcareous nannofossil biostratigraphy of the Cenozoic sections recovered on Leg 103 is presented in Figure 3.

\section{HOLE SUMMARIES}

\section{Hole 637A (Table 1)}

Hole 637A was drilled east of a north-trending basement ridge near the Galicia continental margin $\left(42^{\circ} 05.3^{\prime} \mathrm{N}, 12^{\circ} 51.8^{\prime} \mathrm{W}\right)$ in a water depth of $5307 \mathrm{~m}$. Approximately $212 \mathrm{~m}$ of sediment overlying serpentinized peridotite basement were cored. Three lithostratigraphic units are recognized (see "Site 637" chapter; Shipboard Scientific Party, 1987a):

Unit I: $135 \mathrm{~m}$ of Pleistocene and upper Pliocene gray clay and nannofossil marl interbedded with clayey silt layers. This unit shows many coarse- to fine-grained thin cycles (less than 25 $\mathrm{cm}$ ), characteristic of turbidites.

Unit II: $45 \mathrm{~m}$ of lower Pliocene and upper Miocene brown clay and nannofossil marl. Several slump structures are present.

Unit III: $32 \mathrm{~m}$ of reddish brown and grayish brown clay overlying the serpentinized peridotite basement. Unit III is barren of calcareous nannofossils.

The sedimentary section from this hole yielded calcareous nannofossils ranging from late Miocene to late Pleistocene in age (Table 1). Nannofossils are abundant or common in most of the samples examined and preservation is mostly moderate. All of the nannofossil zones of Okada and Bukry (1980) and Gartner (1977) for this part of the column are recognized, and only one minor hiatus in the Pliocene section is apparent from the stratigraphic sequence. The nannofossil biostratigraphy of Hole $637 \mathrm{~A}$ presented here is basically a refinement of the initial biostratigraphy completed aboard ship and presented in the "Site 637" chapter (Shipboard Scientific Party, 1987a).

Recovery was poor in the first five cores of Hole 637A. A single sample was available from each of these core catchers.

Section 103-637A-1R, CC, is placed in the Emiliania huxleyi Zone based on the presence of $E$. huxleyi, which was confirmed by scanning electron microscopy. Calcidiscus leptoporus, Coccolithus pelagicus, Gephyrocapsa oceanica, Gephyrocapsa spp. (small), and Reticulofenestra spp. (smaller than $5 \mu \mathrm{m}$ ) are common to abundant. Helicosphaera carteri and Rhabdosphaera claviger are few to rare. The Emiliania huxleyi acme Zone (Gartner, 1977) was not detected. 


\begin{tabular}{|c|c|c|c|c|}
\hline Age & Zone & Subzone & Nannofossil datums & $\mathrm{Ma}$ \\
\hline \multirow{6}{*}{$\begin{array}{c}\text { late } \\
\text { Pleistocene }\end{array}$} & \multicolumn{2}{|l|}{ Emiliana hucleyi acme } & EnD 5 hulain & 0085 \\
\hline & \multicolumn{2}{|l|}{ Emiliana hudleyi } & 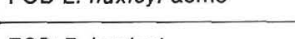 & \\
\hline & \multicolumn{2}{|l|}{ Gephyrocapsa oceanica } & FOD E. huxieyı & 0.275 \\
\hline & \multirow{2}{*}{\multicolumn{2}{|c|}{ Pseudoemiliana lacunosa }} & LOD P. lacunosa & 0.474 \\
\hline & & & highest level of dominantly & 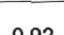 \\
\hline & \multicolumn{2}{|l|}{ small Gephyrocapsa } & Gephyrocapsa & \\
\hline \multirow{2}{*}{$\begin{array}{c}\text { early } \\
\text { Pleistocene }\end{array}$} & \multicolumn{2}{|l|}{ Helicosphaera sellii } & LOD H. sellii & 1.37 \\
\hline & \multirow{2}{*}{\multicolumn{2}{|c|}{ Calcidiscus macintyrei }} & LOD C. macintyrei & 1.45 \\
\hline \multirow{9}{*}{$\begin{array}{c}\text { late } \\
\text { Pliocene }\end{array}$} & & & LOD D. brouweri & 1.9 \\
\hline & \multirow{4}{*}{$\begin{array}{c}\text { Discoaster } \\
\text { brouweri (CN12) }\end{array}$} & CB12d D. triradiatus & LOD $D$. pentaradiatus & 2.35 \\
\hline & & CN12C D. pentaradiatus & LOD D. surculus & 2.4 \\
\hline & & CN12b D. surculus & 100 D tamalis & 26 \\
\hline & & CN12a D. tamalis & & \\
\hline & \multirow{3}{*}{$\begin{array}{c}\text { Reticulofenestra } \\
\text { pseudoumbilica (CN11) }\end{array}$} & \multirow{2}{*}{ CN11b D. asymmetricus } & LOD Sphenolithus spp & 3.5 \\
\hline & & & AD FOD $P$. lacunosa & \\
\hline & & CN11a S. neoabies & LOD A. delicatus or & \\
\hline & \multirow{5}{*}{$\begin{array}{l}\text { Amaurolithus } \\
\text { tricorniculatus (CN10) }\end{array}$} & \multirow{2}{*}{ CN10C C. rugosus } & LOD A. tricorniculatus & 3.7 \\
\hline \multirow{2}{*}{$\begin{array}{c}\text { early } \\
\text { Pliocene }\end{array}$} & & & OD C. rugosus or & 4.57 \\
\hline & & CN10b C. acutus & acutus & \\
\hline \multirow{4}{*}{$\begin{array}{l}\text { late } \\
\text { Miocene }\end{array}$} & & - & $\begin{array}{l}\text { FOD C. acutus or } \\
\text { LOD T. rugosus }\end{array}$ & 5.0 \\
\hline & & & LOD D. quinqueramus & 5.6 \\
\hline & \multirow{2}{*}{$\begin{array}{c}\text { Discoaster } \\
\text { quinqueramus (CN9) }\end{array}$} & CN9b A. primus & FOD A. delicatus & 6.5 \\
\hline & & CN9a D. berggrenii & $\begin{array}{l}\text { FOD } D \text {. berggrenil or } \\
\text { FOD } D \text {. surculus }\end{array}$ & 8.2 \\
\hline
\end{tabular}

Figure 2. Nannofossil zonation adopted for this study (from Bukry, 1973, 1985; Okada and Bukry, 1980; Gartner, 1977). Datum ages are taken from Berggren et al. (1985) and Backman and Shackleton (1983). FOD = first occurrence datum; LOD $=$ last occurrence datum.

Section 103-637A-2R, CC, contains neither Emiliania huxleyi nor Pseudoemiliania lacunosa but rather Calcidiscus leptoporus, Coccolithus pelagicus, Gephyrocapsa oceanica, Gephyrocapsa spp. (small), Helicosphaera carteri, Reticulofenestra spp. (small), and rare Umbilicosphaera sibogae. The preservation is moderate, and the nannofossils are abundant; the sample is assigned to the Gephyrocapsa oceanica Zone (Gartner, 1977).

Section 103-637A-3R, CC, through Sample 103-637A-8R-3, 60-61 cm, are placed in the combined Pseudoemiliania lacunosa Zone/small Gephyrocapsa Zone (Gartner, 1977) based on the presence of Pseudoemiliania lacunosa and the absence of Helicosphaera sellii. The differentiation of these two zones is difficult because of the presence of many turbidite cycles, and the small Gephyrocapsa acme datum level could not be reliably discerned. Nannofossil preservation ranges from good to poor. Pseudoemiliania lacunosa occurs consistently in this interval, as do Calcidiscus leptoporus and Reticulofenestra spp. (small). Coccolithus pelagicus is absent or rare in the lower part of the interval and common in the upper part. Other species within this interval include common Gephyrocapsa spp. (small), Helicosphaera carteri, Rhabdosphaera claviger, few Gephyrocapsa oceanica, and rare Ceratolithus cristatus, Pontosphaera japonica, and Scapholithus fossilis.

The highest stratigraphic occurrence of Helicosphaera sellii is in Section 103-637A-8R, CC. The interval that includes this sample down to Sample 103-637A-10R-1, 6-7 cm, is assigned to the Helicosphaera sellii Zone (Gartner, 1977). The nannofossil flora present in this interval is the same as that in the above zone, except that the abundance of Coccolithus pelagicus is common, Gephyrocapsa caribbeanica is few, and Rhabdosphaera claviger is absent. Within this interval, Sample 103-637A-9R-1, $51-52 \mathrm{~cm}$, is barren of nannofossils.
The lower Pleistocene Calcidiscus macintyrei Zone (Gartner, 1977 ) is defined by the extinction of Discoaster brouweri at the base and that of Calcidiscus macintyrei at the top; Sections 103637A-10R, CC, through 103-637A-11R, CC, are placed in this zone. Because the preservation in this interval is poor, the lower zonal boundary determination is not very reliable. It is possible that the absence of Discoaster brouweri is due to poor preservation rather than its true extinction. In this interval, Coccolithus pelagicus, Gephyrocapsa spp. (small), Helicosphaera carteri, $H$. sellii, Pseudoemiliania lacunosa, and Reticulofenestra spp. (small) are also represented.

Samples 103-637A-12R-1, 43-45 cm, through 103-637A-13R-1, $72-73 \mathrm{~cm}$, are assigned to the Discoaster triradiatus Subzone (CN12d) based on the absence of Discoaster pentaradiatus and $D$. surculus and the presence of $D$. brouweri. Rare D. triradiatus are also present. Sample 103-637A-12R-1, 43-45 cm, is distinct in that it contains abundant Rhabdosphaera claviger, one of the least solution-resistant species (Bergen, 1984).

Samples 103-637A-13R-2, 46-47 cm, to 103-637A-15R-2, 82$83 \mathrm{~cm}$, are placed in the Discoaster surculus Subzone (CN12b). The highest stratigraphic occurrences of both Discoaster surculus and D. pentaradiatus were observed in Sample 103-637A$13 \mathrm{R}-2,46-47 \mathrm{~cm}$; thus, an uncomformity may be present between Samples 103-637A-13R-1, 72-73 cm, and 103-637A-13R$2,46-47 \mathrm{~cm}$, where the entire Discoaster pentaradiatus Subzone (CN12c) and possibly parts of the two adjacent subzones are missing. Discoaster intercalaris is present in most of the samples in this interval, but $D$. tamalis is absent.

Samples 103-637A-15R-4, 48-49 cm, through 103-637A-16R-1, 23-24 cm, are assigned to the Discoaster tamalis Subzone (CN12a). Discoaster tamalis has a very sparse occurrence in this interval; thus, the upper boundary is tentative. The lower boundary is 


\begin{tabular}{|c|c|c|c|c|c|c|c|c|}
\hline Age & Zone/subzone & Hole 637A & Hole 638B & Hole 639A & Hole 639B & Hole $639 \mathrm{c}$ & Hole 639D & Hole 641A \\
\hline \multirow{2}{*}{ late } & E. huxleyi & $1 \mathrm{R}, \mathrm{CC}$ & & 1R-1 & & & & \\
\hline & G. oceanica & $2 \mathrm{R}, \mathrm{CC}$ & & $1 \mathrm{R}, \mathrm{CC} / 3 \mathrm{R}-1$ & $1 \mathrm{R}, \mathrm{CC}$ & & & \\
\hline \multirow{2}{*}{ Pleistocene } & P. lacunosa & \multirow{2}{*}{$3 R, C C 8 R-3$} & & \multirow{3}{*}{$3 R-2 / 3 R-3$} & & & $1 \mathrm{R} r{ }^{2}$ & $1 \mathrm{R}-1$ \\
\hline & small Gephyrocapsa & & & & & & $1+, 60$ & \\
\hline \multirow{2}{*}{ early } & H. sellii & $8 \mathrm{R}, \mathrm{CC} / 10 \mathrm{R}-1$ & & & & & & \\
\hline & C. macintyrei & $10 \mathrm{R}, \mathrm{CC} / 11 \mathrm{R}, \mathrm{CC}$ & $1 R-2 / 2 R-1$ & & & & & \\
\hline \multirow{2}{*}{ late } & CN12d D. triradiatus & 12R-1/13R-1 & & & & & & \\
\hline & CN12c D. pentaradiatus & & & & & & & \\
\hline \multirow{4}{*}{ Pliocene } & CN12b D. surculus & $13 R-2 / 15 R-2$ & & & & & & \\
\hline & CN12a D. tamalis & 15R-4/16R-1 & $2 \mathrm{R}-1 / 4 \mathrm{R}-7$ & & & & & \\
\hline & CN11b D. asymmetricus & $16 R-1 / 17 R-1$ & & & & $1 \mathrm{R}, \mathrm{CC}$ & & \\
\hline & CN11a S. neoabies & 17R-2/17R-3 & & & & & & \\
\hline \multirow{2}{*}{ early } & CN10c C. rugosus & 17R-4 & $4 \mathrm{R}, \mathrm{CC} / 8 \mathrm{R}-7$ & & & & & \\
\hline & CN10b C. acutus & $17 \mathrm{R}, \mathrm{CC} / 18 \mathrm{R}-2$ & 10R-1/11R-2 & & & & & \\
\hline \multirow{3}{*}{$\begin{array}{c}\text { late } \\
\text { Miocene }\end{array}$} & CN10a T. rugosus & \multirow{2}{*}{ 18R-2/19R-2 } & \multirow{2}{*}{ 11R-3/17R-1 } & & & & & \\
\hline & CN9b A. primus & & & & & & & \\
\hline & CN9a D. berggrenii & 19R-2/20R, CC & 17R-2/19R, CC & & & & & \\
\hline
\end{tabular}

Figure 3. Summary of nannofossil biostratigraphy of the Cenozoic sections recovered on Leg 103. Where more than one core is assigned to a single zone/subzone, the highest and lowest sections are listed with a slash between them. $\mathrm{CC}=$ core catcher.

placed at the last occurrence datum (LOD) of Reticulofenestra pseudoumbilica. The assemblage is similar to that of the overlying subzone, but includes rare Discoaster tamalis. Rare Sphenolithus spp. (small) were found in the bottommost sample (Sphenolithus spp. (small), as used in this report, includes Sphenolithus abies, S. compactus, S. moriformis, and S. neoabies, because consistent differentiation between these species is difficult; Backman, 1980; Perch-Nielsen, 1985). The LOD of Sphenolithus spp. in Hole 637A is observed at a slightly higher level than the LOD of Reticulofenestra pseudoumbilica.

The highest stratigraphic occurrence of Reticulofenestra pseudoumbilica is in Sample 103-637A-16R-1, 147-148 cm, and the interval from this sample down to Sample 103-637A-17R-3, 39$40 \mathrm{~cm}$, is placed in the Reticulofenestra pseudoumbilica Zone (CN11).

Samples 103-637A-16R-1, 147-148 cm, to 103-637A-17R-1,' $44-45 \mathrm{~cm}$, are placed in the Discoaster asymmetricus Subzone (CN11b). This interval contains assemblages similar to that of the above subzone (CN12a), plus Reticulofenestra pseudoumbilica, Discoaster variabilis, Syracosphaera pulchra, and Umbilicosphaera sibogae.

Samples 103-637-17A-2R, 10-11 cm, and 103-637A-17R-3, $39-40 \mathrm{~cm}$, are tentatively assigned to the Sphenolithus neoabies Subzone (CN11a) because both Pseudoemiliania lacunosa and Amaurolithus delicatus are absent.

The highest stratigraphic occurrence of Amaurolithus delicatus is in Sample 103-637A-17R-4, 39-40 cm, and the highest stratigraphic occurrence of Ceratolithus acutus is in Section 103-637A-17R, CC; thus, Sample 103-637A-17R-4, 39-40 cm, is placed in the Ceratolithus rugosus Subzone (CN10c).

Section 103-637A-17R, CC, through Sample 103-637A-18R$2,27-28 \mathrm{~cm}$, are placed in the C. acutus Subzone (CN10b) based on the presence of C. acutus. Both Discoaster asymmetricus and Triquetrorhabdulus rugosus are absent in this interval. The preservation of the assemblages is moderate to good.

The highest stratigraphic occurrence of Triquetrorhabdulus rugosus was found in Sample 103-637A-18R-2, 86-87 cm, and the lowest stratigraphic occurrence of $A$. delicatus was observed in Sample 103-637A-19-2, 45-46 cm. This interval is assigned to the T. rugosus Subzone (CN10a)/Amaurolithus primus Subzone (CN9b). Discoaster quinqueramus is very scarce in Leg 103 material, and its LOD could not be used to mark the boundary between Subzones CN10a and CN9b. Minylitha convallis and Discoaster loeblichii were found in this interval.

Sample 103-637A-19R-2, 80-81 cm, to Section 103-637A20R, CC, are assigned to the Discoaster berggrenii Subzone (CN9a) based on the absence of Amaurolithus delicatus and the presence of Discoaster surculus and D. quinqueramus. Section 103-637A-19R, CC, within this interval is barren of nannofossils. Section 103-637A-20R, CC, contains few and poorly preserved nannofossils.

Samples taken from the red-brown clays of lithologic Unit III at the base of the sedimentary section are barren of nannofossils (Sample 103-637A-21R-1, 8-9 cm, through Section 1103$637 \mathrm{~A}-23 \mathrm{R}, \mathrm{CC})$. The only nannofossils recovered from this interval came from isolated sedimentary clasts of calcareous ooze (Sections 103-637A-20R, CC, and 103-637A-21R, CC, and Sample 103-637A-21R-6, $14 \mathrm{~cm}$ ). These clasts contain well-preserved assemblages of early Pliocene age. However, the reliability of the age determinations from these clasts is questionable, because two of these age determinations are from core-catcher samples, which might include downhole cavings. The third sample (103-637A-21R-6, $14 \mathrm{~cm})$ came from an interval of drilling breccia at the base of Core 103-637A-21R.

Several aspects of the nannofossil assemblages in Hole 637 are noteworthy. First, there are very few discoasters in the upper Pliocene sediment samples. This made age determinations difficult because all datums used for this interval are based on last occurrences of discoasters. Second, sphenoliths are rare to absent in most upper Miocene and lower Pliocene samples examined, though they are typically common in low-latitude deep-sea coeval sediment. Third, high abundance of Coccolithus pelagicus was observed throughout the section (except in the upper lower Pleistocene). In present-day oceans, this form has a pref- 
erence for cooler water (McIntyre et al., 1970). The low abundance of discoasters and sphenoliths at Site 637 would also be explained by cooler water, because discoasters and sphenoliths are believed to thrive in warmer low-latitude waters (Haq, 1980). Finally, trace amounts of reworked nannofossils are present in every sample. The amount of reworked nannofossils is constant and never exceeds $1 \%$ of the total assemblage. Common solution-resistant Late Cretaceous forms such as Micula staurophora, Eiffellithus turiseiffeli, Cribrosphaerella ehrenbergii, Zygolithus diplogrammus, and Prediscosphaera cretacea are the most common. Ceratolithoides aculeus, Arkhangelskiella cymbiformis, Rhagodiscus asper, and Eiffellithus eximus were also encountered. Many samples also contain reworked Eocene species such as Discoaster saipanensis and D. barbadiensis. Dictyoccites bisectus, Reticulofenestra umbilica, and Ericsonia formosa were found in many samples. Pliocene sediments at this site contain reworked nannofossils of mostly Miocene forms. Similarly, Pliocene forms were found most frequently in Pleistocene samples. The persistent trace amounts of reworked nannofossils are indicative of erosion and resuspension of material by bottom currents throughout deposition at Site 637.

Nannofossil flora from the nearby DSDP Site 398 also shows the first three aspects as discussed in the preceding, though Blechschmidt (1979) did not report the reworked species and reworking patterns.

\section{Hole 638B (Table 2)}

Hole 638B was drilled on a valley floor that runs roughly parallel to and east of the cuesta formed by resistant carbonate beds at the western edge of a tilted fault block $\left(42^{\circ} 09.2^{\prime} \mathrm{N}\right.$, $12^{\circ} 11.8^{\prime} \mathrm{W}$; water depth, $4661 \mathrm{~m}$ ). The objectives were to obtain reliable data on the very early history of the margin, on the timing of rifting, and on the timing of paleoenvironmental changes in this region of the North Atlantic. A 431-m sedimentary section was drilled at Hole 638B. It includes $184 \mathrm{~m}$ of Cenozoic pelagic ooze overlying $245 \mathrm{~m}$ of Lower Cretaceous marls, limestones, and turbidites. The Cenozoic section yields abundant calcareous nannofossils and is from late Miocene to early Pleistocene in age. Nannofossils are abundant and moderately well preserved in most samples. Assemblages indicate that two unconformities are present in this section. As compared with the initial shipboard results presented in the "Site 638" chapter (Shipboard Scientific Party, 1987b), the results presented here include adjustments to some zonal/subzonal boundaries in the lower Pliocene and upper Miocene sections of this hole.

The first core and the highest sample in the second core (103$638 \mathrm{~B}-2 \mathrm{R}-1,34-35 \mathrm{~cm}$ ) are assigned to the Calcidiscus macintyrei Zone based on the presence of $C$. macintyrei and the absence of discoasters. Nannofossils are abundant in all of the samples, and preservation is good to moderate.

Underlying the Calcidiscus macintyrei Zone is an interval (Samples 103-638B-2R-1, 125-126 cm, through 103-638B-4R-7, 11-12 cm) with a markedly different nannofossil assemblage. Gephyrocapsa caribbeanica and $G$. oceanica are absent, and a diverse assemblage of discoasters $(D$. asymmetricus, $D$. brouweri, $D$. intercalaris, $D$. pentaradiatus, $D$. surculus, D. tamalis, $D$. triradiatus, and $D$. variabilis) is present. Rare Sphenolithus spp. (small), Scyphosphaera lagena, S. penna, and few Syrocosphaera pulchra were also found. Because Reticulofenestra pseudoumbilica is absent, this interval is placed in the Discoaster tamalis Subzone (CN12a). Nannofossils are abundant in all samples and preservation is moderate to good, except for Samples 103-638B-2R-5, 121-122 cm, 103-638B-2R-6, 82-83 cm, in which nannofossils are common to abundant and poorly preserved. As the Discoaster tamalis Subzone (CN12d) and Calcidiscus macintyrei Zone (Gartner, 1977) are determined for subadjacent samples, a major unconformity is present in this hole.
The highest stratigraphic occurrence of Amaurolithus delicatus was found in Section 103-638B-4R, CC. The interval from this section to Sample 103-638B-8R-7, 45-46 cm, is placed in the Ceratolithus rugosus Subzone (CN10c). The lower boundary is tentative because Ceratolithus rugosus is extremely rare in Hole 638B, and the FOD of this species is difficult to recognize. Amaurolithus primus is rare in this interval whereas $A$. delicatus is rare to few and consistently present. The species present in this interval are quite different from those in the overlying zone: Amaurolithus amplificus, $A$. ninae, Sphenolithus spp. (including $S$. abies, S. moriformis, and S. compactus), and Reticulofenestra pseudoumbilica. Pseudoemiliania lacunosa is absent. Within this interval recovery was poor in both Cores 103-638B-5R and 103$638 \mathrm{~B}-6 \mathrm{R}$, and only one sample could be taken from the core catcher of Core 103-638B-6R. Nannofossils are abundant throughout this interval, and the preservation is moderate. The Reticulofenestra pseudoumbilica Zone (CN11) is not recognized, and a lower Pliocene unconformity is present in this hole.

Samples 103-638B-10R-1, 71-72 cm, through 103-638B-11R$2,41-42 \mathrm{~cm}$, are assigned to the Ceratolithus acutus Subzone (CN10b) because Ceratolithus rugosus and Triquetrorhabdulus rugosus are absent, Core 103-638B-9R recovered little sediment ( $1 \%$ core recovery), and a sample from the core catcher yielded only poorly preserved Cretaceous nannofossils.

The highest stratigraphic occurrence of Triquetrorhabdulus rugosus was observed in Sample 103-638B-11R-3, 25-26 cm, and the lowest stratigraphic occurrence of Amaurolithus delicatus was observed in Sample 103-638B-17R, 20-21 cm. This interval is placed in the combined T. rugosus Subzone (CN10a)/ Amaurolithus primus Subzone (CN9b). Differentiation of the two subzones is not possible because Discoaster quinqueramus is absent in Hole 638B. The lower boundary of $A$. primus Subzone (CN9b) is tentatively drawn below Sample 103-638B-17R$1,20-21 \mathrm{~cm}$, as amauroliths are scarce in this hole.

Sample 103-638B-17R-2, 96-97 cm, to Section 103-638B19R, CC, are assigned to the Discoaster berggrenii Subzone (CN9a) because Discoaster surculus is present in this interval. Discoaster loeblichii and Minylitha convallis are present in the lower part of the interval.

As in Hole 637A, sediments from Hole 638B contain very few discoasters. Sphenoliths are also rare to absent. Coccolithus pelagicus is abundant throughout the Cenozoic section. Reworked nannofossils were observed only in one-third of the samples from Hole 638B, but the reworked assemblages are similar to those in Hole 637A.

\section{Hole 639A}

Hole $639 \mathrm{~A}\left(42^{\circ} 08.6^{\prime} \mathrm{N}, 12^{\circ} 14.9^{\prime} \mathrm{W}\right.$; water depth, $\left.4720 \mathrm{~m}\right)$ is one of six holes drilled at Site 639 in an attempt to recover a composite section through the Mesozoic carbonate rocks and penetrate into the basement.

Pleistocene and middle Miocene nannofossil assemblages are present in the $22 \mathrm{~m}$ of Cenozoic sediment of Hole 639A. Sample 103-639A-1R-1, 115-116 cm, contains Emiliania huxleyi and is assigned to the Emiliania huxleyi Zone (Gartner, 1977). Section 103-639A-1R, CC, through Sample 103-639A-3R-1, 17-18 cm, contain Calcidiscus leptoporus, Coccolithus pelagicus, Gephyrocapsa caribbeanica, G. oceanica, and Helicosphaera sellii. Pseudoemiliania lacunosa is absent. This interval is placed in the Gephyrocapsa oceanica Zone (Gartner, 1977). Samples 103-639A3R-2, 115-116 cm, and 103-639A-3R-3, 102-104 cm, contain $P$. lacunosa, $G$. caribbeanica, and $G$. oceanica, but no discoasters, and are early Pleistocene in age. Samples 103-639A-3R-4, 19-20 $\mathrm{cm}$, through 103-639A-4R-1, 1-2 cm, contain Reticulofenestra pseudoumbilica, Triquetrorhabdulus rugosus, and some overgrown discoasters. This interval represents an age older than 
Table 1. Distribution of calcareous nannofossils, Hole 637A. Dashed lines indicate tentative zonal/subzonal boundaries; wavy line indicates hiatus.

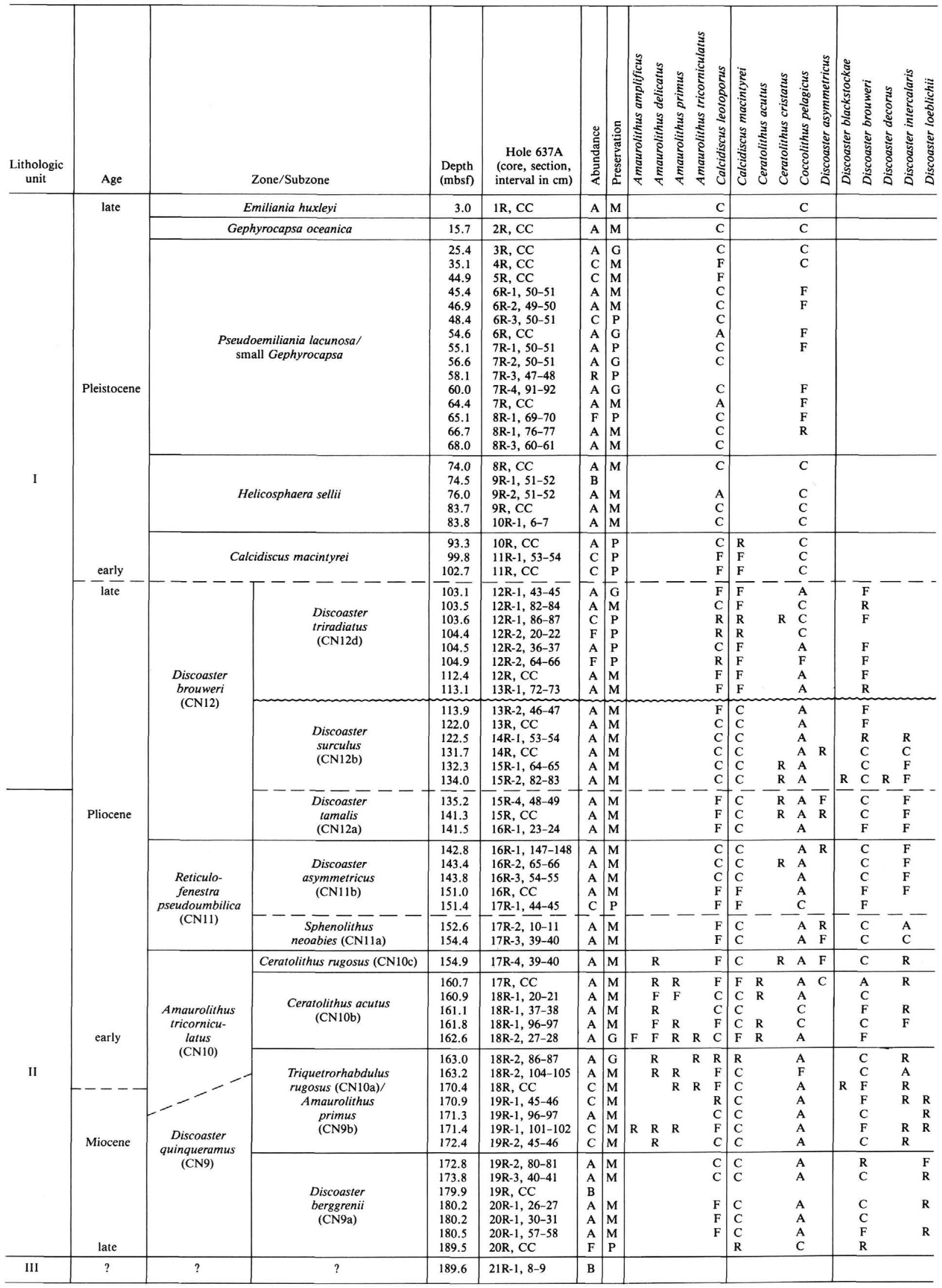

${ }^{\mathrm{a}} \mathrm{A}=$ abundant $\mathrm{C}=$ common; $\mathrm{F}=$ few $\mathrm{R}=$ rare; $\mathrm{B}=$ barren.

${ }^{b} \mathrm{P}=$ poor $\mathbf{M}=$ moderate $\mathrm{G}=$ good. 
Table 1 (continued).

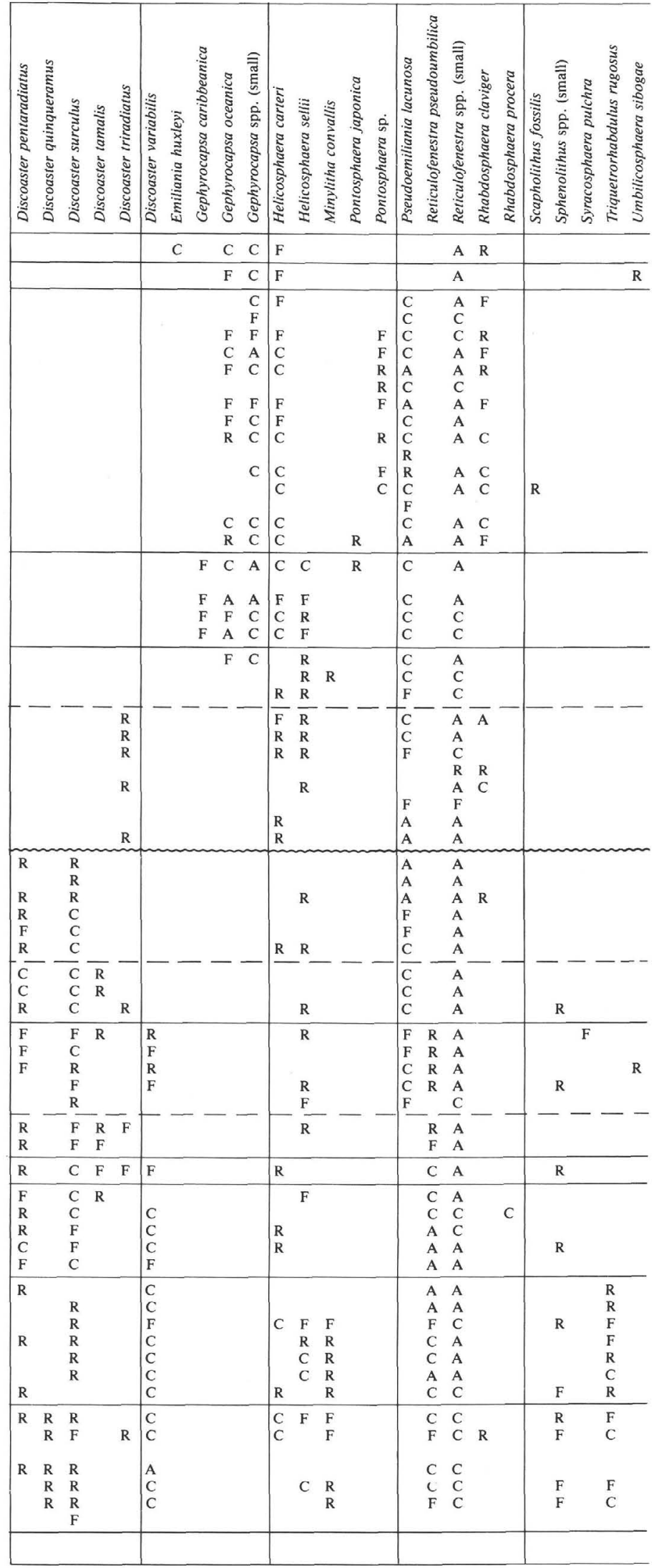


Table 2. Distribution of calcareous nannofossils, Hole 638B. Dashed lines indicate tentative zonal/subzonal boundaries; wavy lines indicate hiatuses.

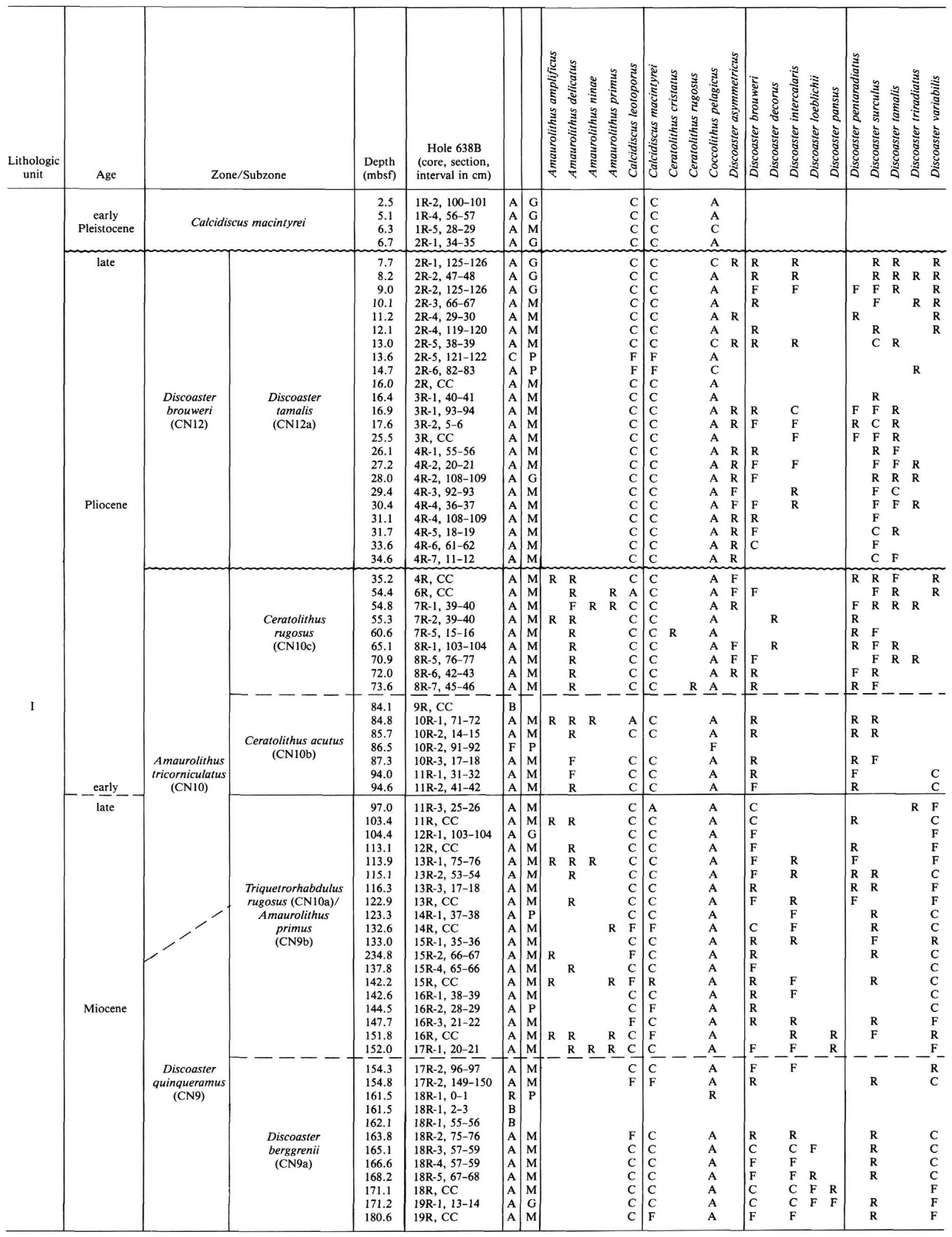

${ }^{\mathrm{a}} \mathrm{A}=$ abundant $\mathrm{C}=$ common; $\mathrm{F}=$ few; $\mathrm{R}=$ rare; $\mathrm{B}=$ barren

${ }^{b} \mathrm{P}=$ poor; $\mathrm{M}=$ moderate; $\mathrm{G}=$ good. 
Table 2 (continued).

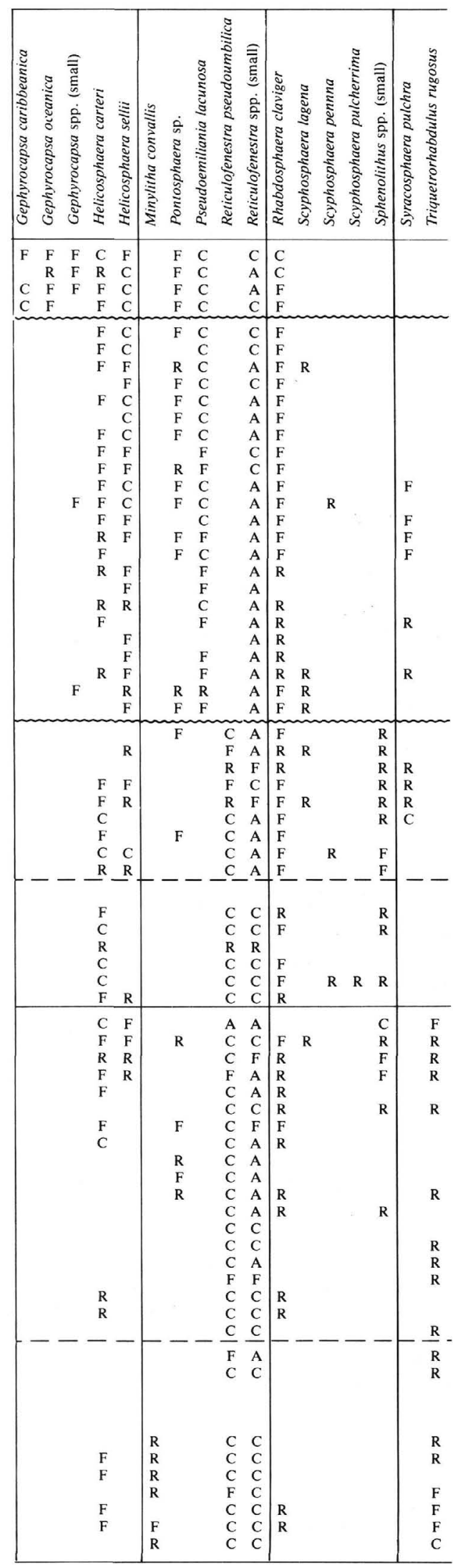

early Pliocene; thus, an unconformity is present between Samples 103-639A-3R-3, 102-104 cm, and 103-639A-3R-4, 19-20 cm.

\section{Hole 639B}

Hole $639 \mathrm{~B}\left(42^{\circ} 08.6^{\prime} \mathrm{N}, 12^{\circ} 15.0^{\prime} \mathrm{W}\right.$; water depth, $\left.4735 \mathrm{~m}\right)$ was drilled $100 \mathrm{~m}$ west of Hole 639A. Abundant and well-preserved late Pleistocene nannofossils of the Gephyrocapsa oceanica Zone (Gartner, 1977) were observed in Section 103-639B-1R, CC. Species present include Calcidiscus leptoporus, Coccolithus pelagicus, Gephyrocapsa caribbeanica, and G. oceanica. The remaining three cores from this hole recovered dolomite, and they are barren of nannofossils.

\section{Hole 639C}

Hole $639 \mathrm{C}\left(42^{\circ} 08.6^{\prime} \mathrm{N}\right.$; $12^{\circ} 15.1^{\prime} \mathrm{W}$; water depth, $\left.4756 \mathrm{~m}\right)$ is $300 \mathrm{~m}$ west of Hole 639A. Two cores were recovered. Core 103639C-1R contains Ceratolithus cristatus, Discoaster asymmetricus, D. brouweri, D. surculus, Pseudoemiliania lacunosa, and Reticulofenestra pseudoumbilica. This interval is placed in the lower Pliocene Discoaster asymmetricus Subzone (CN11b). Samples 103-639C-2R-1, $35 \mathrm{~cm}$, and 103-639C-2R-2, $38 \mathrm{~cm}$, contain brown clay barren of calcareous nannofossils.

\section{Hole 639D}

Hole $639 \mathrm{D}$ is $500 \mathrm{~m}$ west of Hole $639 \mathrm{~A}$ at $42^{\circ} 08.6^{\prime} \mathrm{N}$, $12^{\circ} 15.3^{\prime} \mathrm{W}$ in a water depth of $4748 \mathrm{~m}$. Of the 13 cores recovered from this hole, only Core 103-639D-1R contains Cenozoic nannofossils. Section 103-639D-1R, CC, yielded common, poorly preserved nannofossils lacking gephyrocapsids and discoasters but containing common Calcidiscus macintyrei, Coccolithus pelagicus, and Pseudoemiliania lacunosa. This indicates an early Pliocene to early Pleistocene age.

\section{Hole 641A}

Hole $641 \mathrm{~A}\left(42^{\circ} 09.3^{\prime} \mathrm{N}, 12^{\circ} 10.9^{\prime} \mathrm{W}\right.$; water depth, $\left.4636 \mathrm{~m}\right)$ recovered seven cores, but only one section in the first core contained Cenozoic sediment. The upper $37 \mathrm{~cm}$ of light brown and dark gray marl of Section 103-641A-1X-1 contain common, moderately preserved early Pleistocene nannofossils (Pseudoemiliania lacunosa Zone of Gartner, 1977). Species present include Calcidiscus leptoporus, Gephyrocapsa caribbeanica, G. oceanica, and Pseudoemiliania lacunosa.

Five centimeters of upper Miocene nannofossil ooze containing abundant and moderately preserved nannofossils occur below $37 \mathrm{~cm}$ sub-bottom depth. Sample 103-641A-1X-1, 39-40 cm, contains Amaurolithus delicatus, Discoaster asymmetricus, $D$. brouweri, $D$. pentaradiatus, and $D$. quinqueramus; this interval is placed in the Amaurolithus primus Subzone (CN9b). From Samples 103-641A-1X-1, $42 \mathrm{~cm}$, to 103-641A-1X-1, 60 $\mathrm{cm}$, there are gray layers of lower Pleistocene (Helicosphaera sellii Zone, Gartner, 1977) nannofossil ooze.

Section 103-641A-1X-2 contains isolated strings of nannofossil marl within barren brown clay at the following intervals: $6-7,30-35,40-44,55-58,79-92$, and $108-109 \mathrm{~cm}$. These strings all contain common and poorly preserved nannofossils of late Campanian to early Maestrichtian age. The remainder of Core $103-641 \mathrm{~A}-2 \mathrm{X}$ is a mixture of barren brown clay and lower Pleistocene nannofossil-bearing sediment similar to that in Section 103-641A-1X-1. Within this mixed interval are also a clast of lower Pliocene (Reticulofenestra pseudoumbilica Zone, CN11) nannofossil ooze at 11-12 cm in Section 103-641A-2X-3, an upper Miocene clast (Amaurolithus primus Subzone, CN9b) at $130-132 \mathrm{~cm}$ in Section 103-641A-2X-3, and a layer of upper Maestrichtian nannofossil ooze from 60 to $73 \mathrm{~cm}$ in Section 103-641A-2X-5, containing abundant Micula prinsii.

It is apparent that slumping is present in the $15.7 \mathrm{~m}$ of Cores 103-641 A-1X and 103-641A-2X because of the mixture of sedi- 
ment of different ages, as indicated by the nannofossils and the variety of sediment types encountered. Section 103-641A-3R-1 through Sample 103-641A-6X-7, $27 \mathrm{~cm}$, is barren of nannofossils.

\section{SEDIMENT-ACCUMULATION RATES AND HIATUSES}

Sediment-accumulation rate curves for Holes 637A and 638B are presented in Figures 4 and 5. The sediment-accumulation rates, uncorrected for compaction, were calculated by dividing the thickness of the sediment by time, as indicated by the nannofossil datums.

This study adopts the following ages for the calcareous nannofossil datum levels from the newly adjusted Neogene time scale of Berggren et al. (1985): FOD of Amaurolithus delicatus, 6.5 Ma; LOD of Discoaster quinqueramus, $5.6 \mathrm{Ma}$; LOD of Triquetrorhabdulus rugosus, 5.0 Ma; FOD of Ceratolithus acutus, $5.0 \mathrm{Ma}$; LOD of C. acutus, $4.57 \mathrm{Ma}$; FOD of Ceratolithus rugosus, $4.57 \mathrm{Ma}$; LOD of Amaurolithus delicatus, 3.7 Ma; LOD of Reticulofenestra pseudoumbilica, $3.5 \mathrm{Ma}$; LOD of Discoaster tamalis, 2.6 Ma; LOD of Discoaster surculus, 2.4 Ma; LOD of Discoaster brouweri, 1.9 Ma; LOD of Calcidiscus macintyrei, 1.45 Ma; LOD of Helicosphaera sellii, 1.37 Ma; highest level of dominantly small gephyrocapsids, $0.92 \mathrm{Ma}$; LOD of Pseudo-

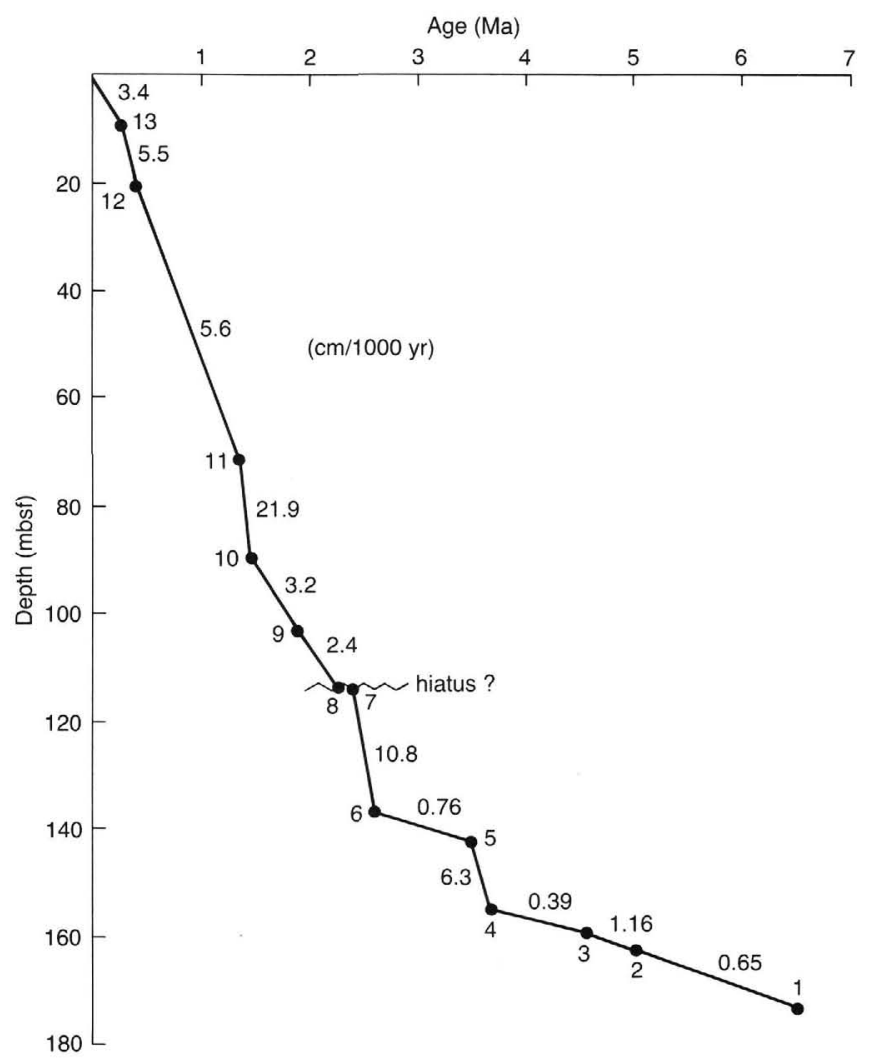

Figure 4. Sediment-accumulation rate diagram for Hole 637A based on nannofossil datums. 1 = FO Amaurolithus delicatus; 2 = LO Triquetrorhabdulus rugosus; 3 = FO Ceratolithus acutus; $4=$ LO Amaurolithus delicatus; 5 = LO Reticulofenestra pseudoumbilica; $6=$ LO Discoaster tamalis $; 7=\mathrm{LO} D$. surculus $; 8=\mathrm{LO} D$. pentaradiatus $; 9=\mathrm{LO}$ D. brouweri $; 10=$ LO Calcidiscus macintyrei $; 11=$ LO Helicosphaera sellii; 12 = LO Pseudoemiliania lacunosa $; 13$ = FO Emiliania huxleyi . All of the datum ages are from Berggren et al. (1985) except that of LO D. pentaradiatus, which is taken from Backman and Shackleton (1983). Hiatus is denoted by a wavy line.

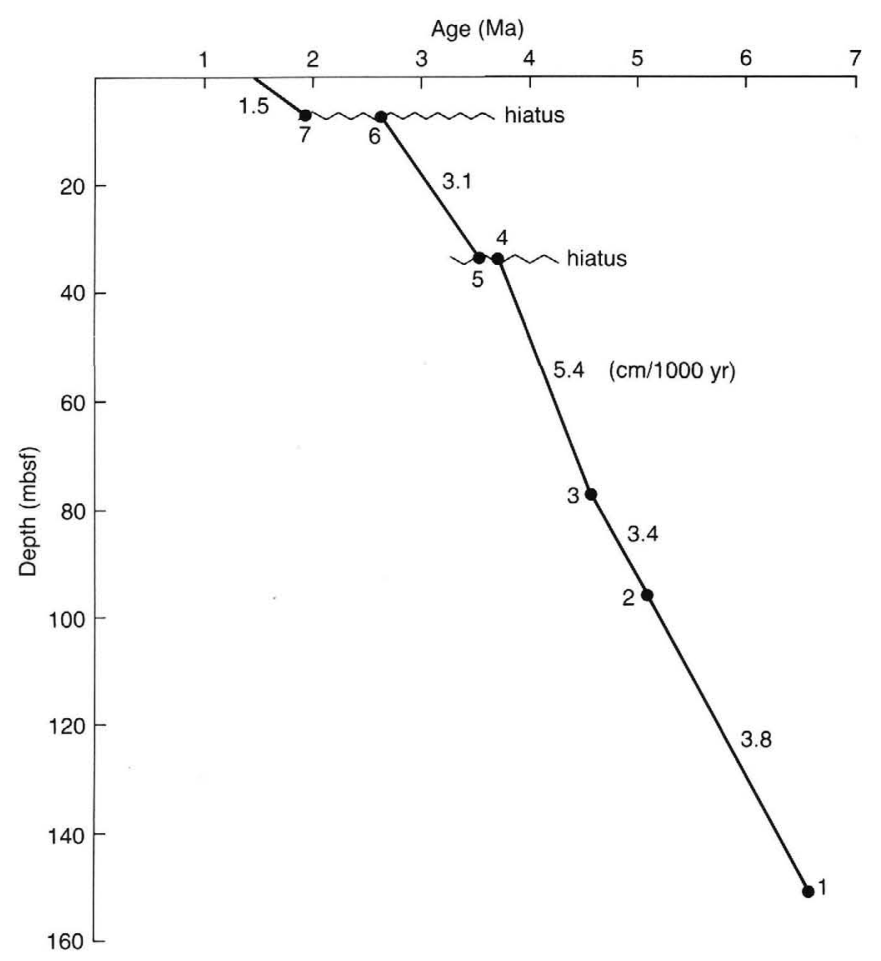

Figure 5. Sediment-accumulation rate diagram for Hole 638B based on nannofossil datums. 1 = FO Amaurolithus delicatus; 2 = LO Triquetrorhabdulus rugosus; 3 = FO Discoaster asymmetricus; $4=$ LO Amaurolithus delicatus; 5 = Reticulofenestra pseudoumbilica; $6=$ LO Discoaster tamalis; $7=$ LO $D$. brouweri. All of the datum ages are from Berggren et al. (1985). Hiatuses are denoted by wavy lines.

emiliania lacunosa, $0.474 \mathrm{Ma}$; FOD of Emiliania huxleyi, 0.275 $\mathrm{Ma}$; and FOD of E. huxleyi acme, $0.085 \mathrm{Ma}$ (see Fig. 3). The age of the LOD of Discoaster pentaradiatus was taken from Backman and Shackleton (1983) because Berggren et al. (1985) gave it the same age as that of the LOD of Discoaster surculus $(2.35 \mathrm{Ma})$, apparently not in agreement with the zonal concepts of Okada and Bukry (1980), which are followed in this paper.

The average sediment-accumulation rate for Hole $637 \mathrm{~A}$ is $2.6 \mathrm{~cm} / 1000$ yr. The highest sediment-accumulation rate $(21.9$ $\mathrm{cm} / 1000 \mathrm{yr}$ ) was observed for the Helicosphaera sellii Zone, which has a time span of $0.08 \mathrm{~m}$.y. An unconformity may be present at a depth of about $114 \mathrm{~m}$ below seafloor (mbsf) because the Discoaster pentaradiatus Subzone (CN12c) was not observed. Lang and Wise (1987) recognized a similar hiatus at DSDP Site 604 (continental rise off New Jersey). The time represented by this hiatus coincides with the onset of Northern Hemisphere continental glaciation, which Backman (1979) and Shackleton and Kennett (1975) dated at about 2.4 to 2.5 Ma. It is also possible that the $D$. pentaradiatus Subzone was not sampled because this subzone represents a very short time period ( $0.05 \mathrm{~m} . \mathrm{y}$.$) , whereas the sampling interval here is 1.25 \mathrm{~m}$.

The sediment-accumulation rate curve for Hole $638 \mathrm{~B}$ is presented in Figure 5. The average sediment-accumulation rate for the post-Miocene section at this site is $1.9 \mathrm{~cm} / 1000 \mathrm{yr}$. The sediment-accumulation rates for each of the nannofossil zones are close to the average rate at this site. As discussed in "Site 638" chapter (Shipboard Scientific Party, 1987b), the missing upper Pleistocene section in Hole 638B could be present in the $6 \mathrm{~m}$ that was not cored. However, even if the $6 \mathrm{~m}$ of sediment were added to the sediment-accumulation rate calculation for the Pleistocene, the rate would still be low $(0.7 \mathrm{~cm} / 1000 \mathrm{yr})$. This is in contrast with that in Hole $637 \mathrm{~A}$, where the sediment-accumulation rate is high for the entire Pleistocene section (average 5.4 
$\mathrm{cm} / 1000 \mathrm{yr}$ ). Therefore, a large part of Pleistocene section at Site 638 could be missing. This may indicate strong bottom currents in this valley during the Pleistocene, and nondeposition and removal of sediment must have occurred.

A major hiatus is recognized at and below the Pliocene/ Pleistocene boundary at a depth between 6.7 and $7.7 \mathrm{mbsf}$. The minimum time represented by this hiatus is 0.77 m.y. Another hiatus in Hole 638B is present at a depth of about $35 \mathrm{mbsf}$, where the Reticulofenestra pseudoumbilica Zone (CN11) is missing. The time span of the nannofossil zone is from 3.7 to 3.5 Ma. The hiatus may include parts of both the zones above and below the $R$. pseudoumbilica Zone. This hiatus coincides in time with the event when the Gulf Stream increased its intensity due to the uplifting of the Isthmus of Panama, thereby closing the marine connection between the Atlantic and Pacific oceans (Berggren and Hollister, 1974; Saito, 1976; Keigwin, 1982).

\section{COCCOLITHUS PELAGICUS/DISCOASTER BROUWERI RATIOS AND THEIR IMPLICATIONS}

Coccolithus pelagicus prefers cool waters, whereas Discoaster brouweri thrived in warmer waters (McIntyre et al., 1970; Bukry, 1971, 1973; Siesser, 1975; Haq, 1980). The abundance ratio of Coccolithus pelagicus abundance to that of $D$. brouweri may therefore provide an estimate of the relative paleotemperature changes of the surface water.

The use of this ratio has the following advantages:

1. Both $C$. pelagicus and $D$. brouweri have long stratigraphic ranges. $C$. pelagicus ranges from the Paleocene to the present and $D$. brouweri from the early late Miocene through the Pliocene, which enables observation of their abundance changes over a relatively long time span.

2. C. pelagicus is among the most common species present in most oceanic sediment, whereas $D$. brouweri is usually one of the most common warm-water species in most deep-sea sediment. Therefore, observation of them is easy and consistent.

3. Both species are among the most dissolution-resistant forms (Bukry, 1973; Wise, 1973; Roth et al., 1975). Thus, they are less subject to diagenetic effects and better represent the original environment.

4. The use of the abundance ratio of $C$. pelagicus to $D$. brouweri instead of their absolute abundance in the sediment filters out variation in sediment-accumulation rates, variation in slide thickness, dissolution bias, and other factors so that the ratio values are a better reflection of the paleotemperature of the surface waters.

The $C$. pelagicus $/ D$. brouweri ratios for Holes $637 \mathrm{~A}$ and 638B have been plotted in Figures 6 and 7.

It is interesting to note from Figure 6 that between 6.5 and $2.5 \mathrm{Ma}, C$. pelagicus $/ D$. brouweri ratio values are low, fluctuate little, and are quite similar in trend to the stable isotopic records from the North Pacific (Keigwin, 1979), equatorial Pacific (Keigwin, 1979, 1982), South Atlantic (Leonard et al., 1983), Caribbean (Keigwin, 1982), and Mediterranean (Thunell and Williams, 1983), which suggests a relatively higher and stable surface-water temperature at Site 637 for that time.

After about $2.5 \mathrm{Ma}, C$. pelagicus $/ D$. brouweri ratio values increase sharply and fluctuate widely. This change coincides in time with the deposition of the oldest ice-rafted debris in the northern Atlantic Ocean (Backman, 1979) and the oldest loess deposits in China (Heller and Li, 1984) and may therefore be related to the onset of widespread Northern Hemisphere glaciation (Shackleton and Kennett, 1975). The fluctuation of ratio values in the late Pliocene may be due to multiple glacial-interglacial cycles.

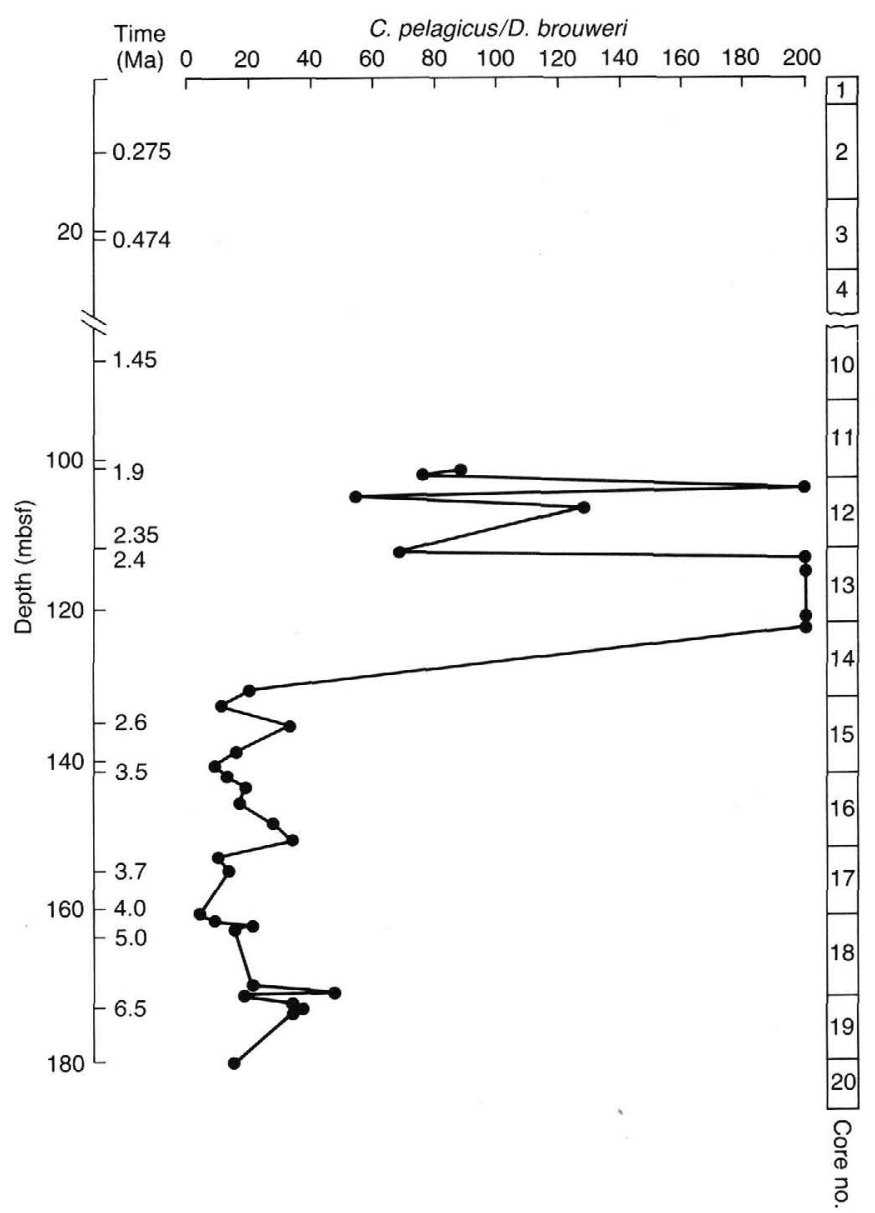

Figure 6. Coccolithus pelagicus/Discoaster brouweri ratio diagram for Hole 637A. Ratios plotted at a value of 200 indicate samples in which 200 specimens of $C$. pelagicus were counted without encountering $D$. brouweri during random track counting. Ages are from Berggren et al. (1985).

C. pelagicus/D. brouweri ratios for Hole 638B presented in Figure 7 show many fluctuations, though the general trend is that the ratios increase with time in the late Miocene and early Pliocene. With the data presently available, it is very difficult to interpret these fluctuations. The ratio record of Hole 638B differs from that of Hole 637A, as do the sediment-accumulation rates and nannofossil species abundances. Meaningful interpretation of these differences can not be made until more data are available.

\section{SUMMARY}

Two holes (637A and 638B) from the ODP Leg 103 yielded significant Cenozoic sedimentary sections ranging from late $\mathrm{Mi}$ ocene to late Pleistocene in age. Calcareous nannofossils are abundant or common and moderately well preserved in most of the samples examined. Nannofossil zones were determined for the midlatitude area drilled using a modification of the schemes proposed by Bukry $(1973,1985)$, Okada and Bukry (1980), and Gartner (1977). Two emendations of their schemes are made: the datum level marked by the beginning of the acme of Discoaster asymmetricus is replaced by the FOD of Pseudoemiliania lacunosa and the FOD of Amaurolithus delicatus is substituted for that of $A$. primus. In Hole 637A, all of the nannofossil zones or subzones from Discoaster quinqueramus Zone (CN9) 


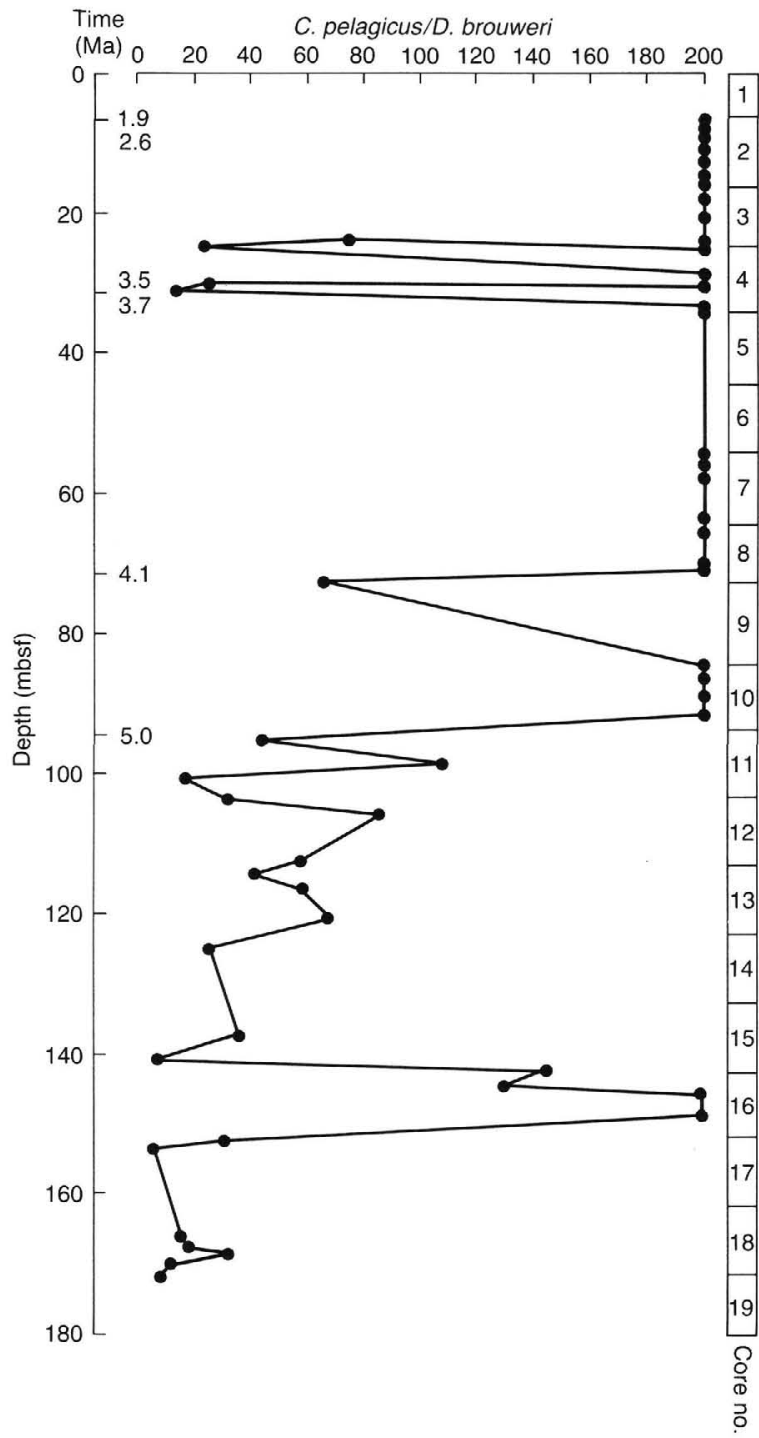

Figure 7. Coccolithus pelagicus/Discoaster brouweri ratio diagram for Hole 638B. Ratios plotted at a value of 200 indicate samples in which 200 specimens of $C$. pelagicus were counted without encountering $D$. brouweri during random track counting. Ages are from Berggren et al. (1985).

to Emiliania huxleyi Zone are present, except for the Discoaster pentaradiatus Subzone (CN12c). Cenozoic nannofossil zones from D. quinqueramus Zone to the Calcidiscus macintyrei Zone are identified in Hole 638B. Two major hiatuses, one at 1.9-2.6 Ma and another at 3.5-3.7 Ma, are present in Hole 638B. Sedimentaccumulation rates for Holes 637A and 638B have been calculated based on the ages of nannofossil datums taken from Berggren et al. (1985) and Backman and Shackleton (1983). The variation in abundance of the cool-water species Coccolithus pelagicus and that of warm-water species Discoaster brouweri have been observed for Holes 637A and 638B. The C. pelagicus/D. brouweri ratios from Hole 637A show relatively lower, stable values between 6.5 to $2.5 \mathrm{Ma}$, indicating relatively higher and stable surface-water temperature at that time. Beginning at about 2.5 $\mathrm{Ma}$, the $C$. pelagicus $/ D$. brouweri ratio values sharply increase and fluctuate widely, suggesting relatively lower and unstable surface-water temperatures. This change coincides in time with the onset of widespread Northern Hemisphere glaciation. The fluctuation of the $C$. pelagicus $/ D$. brouweri ratios during the late Pliocene may be related to the multiglacial-interglacial cycles. The $C$. pelagicus $/ D$. brouweri ratios from Hole 638B also show increasing values with time from the late Miocene to the late Pliocene but show much more fluctuation and a different pattern than the record of Hole 637A.

\section{ACKNOWLEDGMENTS}

We thank David Bukry, Marie-Pierre Aubry, Audrey Meyer, and Michel Moullade for their critical reviews and helpful suggestions, which have significantly improved this paper. Special thanks go to Sherwood Wise, who encouraged us to participate in ODP research and provided guidance during the study.

\section{REFERENCES}

Backman, J., 1979. Pliocene biostratigraphy of DSDP Sites 111 and 116 from the North Atlantic Ocean and the age of Northern Hemisphere glaciation. Stockholm Contrib. Geol., 32:115-137. 1980. Miocene-Pliocene nannofossils and sedimentation rates in the Hatton-Rockall basin, NE Atlantic Ocean. Stockholm Contrib. Geol., 36:1-91.

Backman, J., and Shackleton, N. S., 1983. Quantitative biochronology of Pliocene and early Pleistocene calcareous nannofossils from the Atlantic, Indian, and Pacific oceans. Mar. Micropaleontol., 8:141170.

Bergen, J. A., 1984. Calcareous nannoplankton from Deep Sea Drilling Project Leg 78A: evidence for imbricate underthrusting at the Lesser Antillian active margin. In Biju-Duval, B., Moore, J. C., et al., Init. Repts. DSDP, 78A: Washington (U.S. Govt. Printing Office), 411445.

Berggren, J. A., and Hollister, C. D., 1974. Paleoceanography, paleobiogeography and the history of circulation in the Atlantic Ocean. In Hay, W. W. (Ed.), Study in Paleoceanography: Spec. Publ. Soc. Econ. Paleontol. Mineral., 20:126-187.

Berggren, W. A., Kent, D. V., and van Couvering, J. A., 1985. The chronology of the geological record. Mem. Geol. Soc. Am., 10:141195.

Blechschmidt, G., 1979. Biostratigraphy of calcareous nannofossils: Leg 47B, Deep Sea Drilling Project. In Sibuet, J.-C., Ryan, W.B.F., et al., Init. Repts. DSDP, 47, Pt. 2: Washington (U.S. Govt. Printing Office), 327-360.

Bukry, D., 1971. Coccolith stratigraphy, Leg 6, Deep Sea Drilling Program. In Fischer, A. G., Heezen, B. C., et al., Init. Repts. DSDP, 6: Washington (U.S. Govt. Printing Office), 965-1003.

1973. Coccolith stratigraphy, Eastern Pacific, Leg 16, DSDP. In van Andel, T. H., Heath, G. R., et al., Init. Repts. DSDP, 16: Washington (U.S. Govt. Printing Office), 653-711.

, 1981. Cenozoic coccoliths from the Deep Sea Drilling Project: a decade of progress: Spec. Publ. Soc. Econ. Paleontol. Mineral., 30:433-444.

1985. Mid-Atlantic Ridge coccolith and silicoflagellate biostratigraphy, Deep Sea Drilling Project Sites 558 and 563. In Bougault, H., Cande, S. C., et al., Init. Repts. DSDP, 82: Washington (U.S. Govt. Printing Office), 591-603.

Ellis, C. H., and Lohman, W. H., 1979. Neogene calcareous nannoplankton biostratigraphy in eastern Mediterranean deep-sea sediments (Deep Sea Drilling Project Leg 42A, Sites 375 and 376). Mar. Micropaleontol., 4:61-84.

Gartner, S., 1977. Calcareous nannofossil biostratigraphy and revised zonation of the Pleistocene. Mar. Micropaleontol., 2:1-25.

Haq, B. U., 1980. Biostratigraphy of Miocene calcareous nannoplankton and paleoceanography of the Atlantic Ocean. Micropaleontology, 26:414-443.

Haq, B. U., and Berggren, W. A., 1978. Late Neogene calcareous plankton biochronology of the Rio Grande Rise (South Atlantic Ocean). J. Paleontol., 52:1167-1194.

Hay, W. W., 1970. Calcareous nannofossils from cores recovered on Leg 4. In Bader, R. G., Gerard, R. D., et al., Init. Repts. DSDP, 4: Washington (U.S. Govt. Printing Office), 455-501.

Heller, F., and Li, T., 1984. Magnetism of Chinese loess deposits. Geophys. J. R. Astron. Soc., 77:125-141.

Heller, F., and Li, T., 1984. Magnetism of Chinese loess deposits. Geophys. J. R. Astron. Soc., 77:125-141.

Keigwin, L. D., Jr., 1979. Late Cenozoic stable isotope stratigraphy and paleoceanography of DSDP sites from the east equatorial and north 
central Pacific Ocean. Earth Plant. Sci. Lett., 45:361-382. 1982. Stable isotope stratigraphy and paleoceanography of Sites 502 and 503. In Prell, W. L., Gardner, J. V., et al., Init. Repts. $D S D P, 68$ : Washington (U.S. Govt. Printing Office), 445-453.

Lang, T. H., and Wise, S. W., 1987. Neogene and Paleogene/Maestrichtian calcareous nannofossil stratigraphy, Deep Sea Drilling Project Sites 604 and 605, upper continental rise off New Jersey: sedimentation rates, hiatuses, and correlations with seismic stratigraphy. In van Hinte, J. E., Wise, S. W., et al., Init. Repts. DSDP, 93: Washington (U.S. Govt. Printing Office), 661-711.

Leonard, K. A., Williams, D. F., and Thunell, R. C., 1983. Pliocene paleoclimatic history and paleoceanographic history of the South Atlantic Ocean: stable isotopic records from Leg 77 Deep Sea Drilling Project Holes 516A and 517. In Barker, P. F., Carlson, R. L., Johnson, D. A., et al., Init. Repts, DSDP, 72: Washington (U.S. Govt. Printing Office), 895-906.

Loeblich, A. R., Jr., and Tappan, H., 1966. Annotated index and bibliography of the calcareous nannoplankton, I. Phycologia, 5:81-216. 1968. Annotated index and bibliography of the calcareous nannoplankton, II. J. Paleontol., 42:584-598.

1969. Annotated index and bibliography of the calcareous nannoplankton, III. J. Paleontol., 43:568-588.

1970a. Annotated index and bibliography of the calcareous nannoplankton, IV. J. Paleontol., 44:558-574.

, 1970b. Annotated index and bibliography of the calcareous nannoplankton, V. Phycologia, 9:157-174.

1971. Annotated index and bibliography of the calcareous nannoplankton, VI. Phycologia, 10:315-339.

1973. Annotated index and bibliography of the calcareous nannoplankton, VII. J. Paleontol., 47:715-759.

Lohman, W. H., 1986. Calcareous nannoplankton biostratigraphy of the Southern Coral Sea, Tasman Sea, and southwestern Pacific Ocean, Deep Sea Drilling Project Leg 90: Neogene and Quaternary. In Kennett, J. P., von der Borch, C. C., et al., Init. Repts. DSDP, 90: Washington (U.S. Govt. Printing Office), 763-793.

McIntyre, A., Bé, A.W.H., and Roche, M. B., 1970. Modern Pacific Coccolithoporida: a paleontological thermometer. Trans. N.Y. Acad. Sci., 32:720-731.

Okada, H., and Bukry, D., 1980. Supplementary modification and introduction of code numbers to the low-latitude coccolith biostratigraphic zonation (Bukry, 1973; 1975). Mar. Micropaleontol., 5:321325.

Perch-Nielsen, K., 1985. Cenozoic calcareous nannofossils. In Bolli, H. M., Saunders, J. B., and Perch-Nielsen, K. (Eds.), Plankton Stratigraphy: Cambridge (Cambridge Univ. Press), 427-554.

Roth, P. H., Wise, S. W., and Thiestein, H., 1975. Early chalk diagenesis and lithification: sedimentological applications of paleontological approach. Congr. Int. Assoc. Sedimentol., 9(7):187-192.

Saito, T., 1976. Geologic significance of coiling direction in planktonic foraminifera Pulleniatina. Geology, 4:305-309.

Sclater, J. G., Meinke, L., Bennett, A., and Murphy, C., 1985. The depth of the ocean through the Neogene. In Kennett, J. P. (Ed.), The Miocene Ocean: Paleoceanography and Biogeography: Mem. Geol. Soc. Am., 163:1-19.

Shackleton, N. J., and Kennett, J. P., 1975. Late Cenozoic oxygen and carbon isotopic changes at DSDP Site 284: implications for glacial history of the northern hemisphere. In Kennett, J. P., Houtz, R. E., et al., Init. Repts. DSDP, 29: Washington (U.S. Govt. Printing Office), 801-807.

Shipboard Scientific Party, 1987a. Site 637. In Boillot, G., Winterer, E. L., et al., Proc. ODP, Init. Repts., 103: College Station, TX (Ocean Drilling Program), 123-219.

, 1987b. Site 638. In Boillot, G., Winterer, E. L., et al., Proc. ODP, Init. Repts., 103: College Station, TX (Ocean Drilling Program), 221-407.

Siesser, W. G., 1975. Calcareous nannofossils from the South African continental margin. Mar. Geol. Prog., 5:1-135.

Sibuet, J.-C., Ryan, W.B.F., et al., 1979. Init. Repts. DSDP, 47, Pt. 2 : Washington (U.S. Govt. Printing Office).

Steinmetz, J. C., 1984a. Bibliography and taxa of calcareous nannoplankton, III. Int. Nannoplankton Assoc. Newsl., 6:6-37.

, 1984b. Bibliography and taxa of calcareous nannoplankton, IV. Int. Nannoplankton Assoc. Newsl., 6:55-81.

1985a. Bibliography and taxa of calcareous nannoplankton, V. Int. Nannoplankton Assoc. Newsl., 7:5-28. 1985b. Bibliography and taxa of calcareous nannoplankton, VI. Int. Plankton Assoc. Newsl., 7:50-78.

1986. Bibliography and taxa of calcareous nannoplankton, VII. Int. Nannoplankton Assoc. Newsl., 8:12-32.

Thunnell, R. T., and Williams, D. F., 1983. The stepwise development of Pliocene-Pleistocene paleoclimatic and paleoceanographic conditions in the Mediterranean: oxygen isotopic studies of DSDP Sites 125 and 132. Utrecht Micropaleontol. Bull., 30:111-127.

van Heck, S. E., 1979a. Bibliography and taxa of calcareous nannoplankton. Int. Nannoplankton Assoc. Newsl., 1:AB1-AB5, A1-A12, B1-B27.

1979b. Bibliography and taxa of calcareous nannoplankton. Int. Nannoplankton Assoc. Newsl., 1:AB-VI, A13-A28, B28-B42. 1980a. Bibliography and taxa of calcareous nannoplankton. Int. Nannoplankton Assoc. Newsl., 2:5-34.

$1980 \mathrm{~b}$. Bibliography and taxa of calcareous nannoplankton.

Int. Nannoplankton Assoc. Newsl., 2:43-81.

1981a. Bibliography and taxa of calcareous nannoplankton.

Int. Nannoplankton Assoc. Newsl., 3:4-41.

$1981 \mathrm{~b}$. Bibliography and taxa of calcareous nannoplankton.

Int. Nannoplankton Assoc. Newsl., 3:51-86.

, 1982a. Bibliography and taxa of calcareous nannoplankton.

Int. Nannoplankton Assoc. Newsl., 4:7-50.

, 1982b. Bibliography and taxa of calcareous nannoplankton.

Int. Nannoplankton Assoc. Newsl., 4:65-96.

1983. Bibliography and taxa of calcareous nannoplankton. Int. Nannoplankton Assoc. Newsl., 5:4-13.

Wise, S. W., 1973. Calcareous nannofossils from cores recovered by Leg 18. DSDP: biostratigraphy and observations of diagenesis. In Kulm, L. D., von Huene, R., et al., Init. Repts. DSDP; 18: Washington (U.S. Govt. Printing Office), 569-616.

Date of initial receipt: 7 January 1987

Date of acceptance: 1 May 1987

Ms 103B-143

\section{APPENDIX A}

Nannofossil Species Considered in this Paper

Most of the bibliographic references for the taxa are presented by Loeblich and Tappan $(1968,1969,1970 \mathrm{a}, 1970 \mathrm{~b}, 1971,1973)$, van Heck (1979a, 1979b, 1980a, 1980b, 1981a, 1981b, 1982a, 1982b, 1983), and Steinmetz (1984a, 1984b, 1985a, 1985b). Any references not included in these are included in the references of this paper.

Amaurolithus amplificus (Bukry and Percival) Gartner and Bukry, 1975 Amaurolithus delicatus Gartner and Bukry, 1975

Amaurolithus primus (Bukry and Percival) Gartner and Bukry, 1975

Amaurolithus ninae Perch-Nielsen, 1977

Amaurolithus tricorniculatus (Gartner) Gartner and Bukry, 1975

Calcidiscus leptoporus (Murray and Blackman) Loeblich and Tappan, 1978

Calcidiscus macintyrei (Bukry and Bramlette) Loeblich and Tappan, 1978

Ceratolithus acutus Gartner and Bukry, 1974

Ceratolithus cristatus Kamptner, 1950

Coccolithus pelagicus (Wallich) Schiller, 1930

Discoaster asymmetricus Gartner, 1969

Discoaster berggrenii Bukry, 1971

Discoaster blackstockae Bukry, 1973

Discoaster brouweri Tan 1927

Discoaster decorus (Bukry) Bukry, 1973

Discoaster intercalaris Bukry, 1971

Discoaster loeblichii Bukry, 1971

Discoaster pansus (Bukry and Percival) Bukry, 1973

Discoaster pentaradiatus Tan, 1927, emend. Bramlette and Riedel, 1954

Discoaster quinqueramus Gartner, 1969

Discoaster surculus Bramlette and Martini, 1963

Discoaster tamalis Kamptner, 1967

Discoaster triradiatus Tan, 1927

Discoaster variabilis Bramlette and Martini, 1963

Emiliania huxleyi (Lohmann) Hay and Moler, in Hay et al., 1976

Gephyrocapsa caribbeanica Boudreaux and Hay, 1967

Gephyrocapsa oceanica Kamptner, 1943 
Helicosphaera carteri (Wallich) Kamptner, 1954

Helicosphaera sellii (Bukry and Bramlette) Jafar and Martini, 1975 Minylitha convallis Bukry, 1973

Pontosphaera japonica (Takayama) Nishida, 1973

Pseudoemiliania lacunosa (Kamptner) Gartner, 1969

Reticulofenestra pseudoumbilica (Gartner) Gartner, 1969

Rhabdosphaera clavigera Murray and Blackman, 1898

Rhabdosphaera procera Martini, 1969

Scapholithus fossilis Deflandre in Deflandre and Fert, 1954
Scyphosphaera lagena Kamptner, 1955

Scyphosphaera penna Kamptner, 1955

Sphenolithus compactus Backman, 1980

Sphenolithus moriformis (Bronnimann and Stradner) Bramlette and Wilcoxon, 1967

Sphenolithus neoabies Bukry and Bramlette, 1969

Syracosphaera pulchra Lohmann, 1902

Triquetrorhabdulus rugosus Bramlette and Wilcoxon, 1967

Umbilicosphaera sibogae (Weber-van Bosse) Gaarder, 1970 